Activités

4-2 | octobre 2007

ATWAD

\title{
Collaborative development of a new concept for an activity
}

Jaakko Virkkunen

\section{(2) OpenEdition \\ Journals}

Electronic version

URL: http://journals.openedition.org/activites/1769

DOI: 10.4000/activites.1769

ISSN: $1765-2723$

\section{Publisher}

ARPACT - Association Recherches et Pratiques sur les ACTivités

Electronic reference

Jaakko Virkkunen, "Collaborative development of a new concept for an activity », Activités [Online], 4-2 I octobre 2007, Online since 15 October 2007, connection on 01 May 2019. URL : http:// journals.openedition.org/activites/1769; DOI : 10.4000/activites.1769

\section{(ब) $(\oplus \Theta$}

Activités est mis à disposition selon les termes de la licence Creative Commons Attribution - Pas d'Utilisation Commerciale - Pas de Modification 4.0 International. 


\title{
Collaborative development of a new concept for an activity
}

\author{
Jaakko Virkkunen \\ Center for Activity Theory and Developmental Work Research, Department of Education, University of Helsinki. P.O. \\ Box 26 FIN-00014 University of Helsinki, Finland
}

\begin{abstract}
In all productive activities in the market economy there is a fundamental inner contradiction between the use value of a produced commodity and its exchange value in the markets. Each technological revolution profoundly changes the conditions of balancing these contradictory demands by enabling the creation of new kinds of use values, the reduction of costs, and a broadened exchange. The culturally available forms of activity can be seen as different concepts of balancing contradictory demands. Currently, the concept of mass production is being replaced by new concepts which utilize the possibilities that the new digital information and communication technologies provide. The creation and implementation of a new concept for an activity is, however, a complex process in which many complementary innovations must be integrated into a functioning whole. In this paper, I will discuss the possibility of applying the principle of collective invention in the creation of a new operating concept.
\end{abstract}

KEYWORDS:

Historical types of work, the concept of an activity, activity system, collective invention

\section{1.- The concept of an activity}

The development of systems of productive activity does not proceed linearly, but though cycles of transformation in which the logic of the activity changes. Such changes are invariably connected to an expansive redefinition of the object and outcome of the activity as well as the development of related new tools and forms of collaboration. In the market economy, such transformations become inevitable when an imbalance develops between the use value of the produced commodities and their exchange value in the markets. Radical technological innovations, especially those that create a new infrastructure for production and exchange, change the conditions of balancing these contradictory demands. Therefore, each era produces a number of specific principles and types of logic of balancing them in the specific technological and market conditions of the time. These can be seen as concepts that provide the basis of securing mutual compatibility between the elements of an activity system.

According to Freeman and Louça (2000), the long period of economic growth from 1945 to 1973 was based on the utilization of cheap energy and the extended possibilities of transportation created by the invention of the internal combustion engine and oil refining technology. The new resource was utilized by applying the principles of mass production which became the dominant concept of organizing work activities at that time. The mass production concept was applied, mutatis mutandis, in almost all areas of material production and services. 
Bart Victor and Andrew Boynton (1998) have presented a model of the historical trajectory of the development of forms of work - which in our terminology can also be seen as different concepts for production activities (see Figure 1). According to them, the next developmental stage is always based on reconfigurating the capabilities created in the previous one in order to adapt the activity to changing market conditions.

Victor and Boynton maintain that each local activity has to go through the 'right path' of the sequence of original historical development of the activity concepts. They see craft work as the basis of all the others because there the basic know-how of a specific product is created. The transition to mass production becomes necessary as the volume of the activity increases. The transition is mainly about explicating, disintegrating, optimizing, enlarging, standardizing and retooling of the production process. The prevalent features of the mass-production concept are the sequential organization of work, strong functional specialization, and centralized, hierarchical decision making.

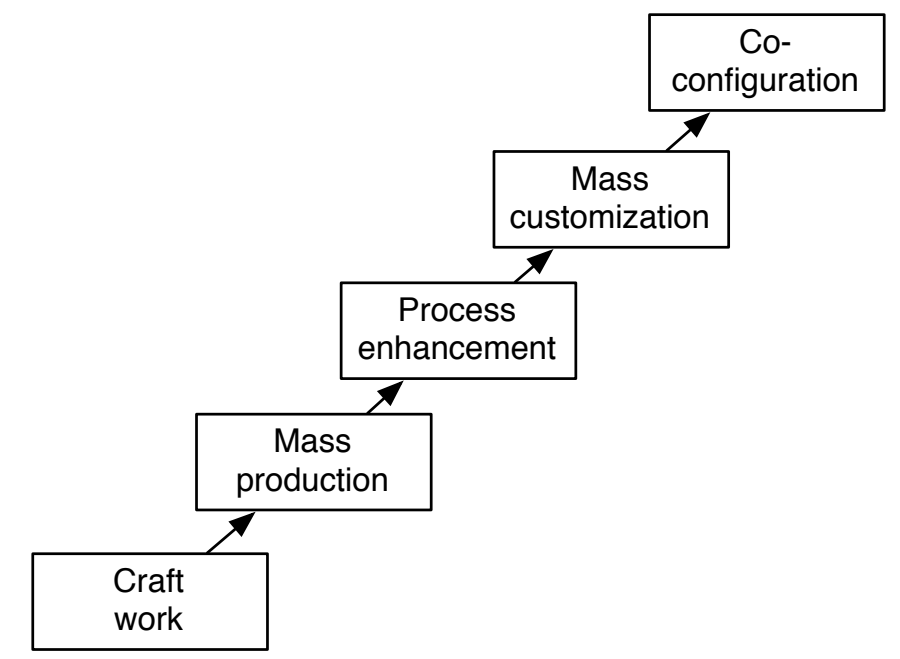

Figure 1. Historical types of work according to Victor and Boynton

The process enhancement concept, that is, the concept of flexible mass production, was originally developed at Toyota in the years 1945-1973 (Ohno, 1978). It spread internationally because of its good results and because it was better suited to the conditions of increasingly saturated markets for mass products. Process enhancement adds a feature of reciprocity and feedback to the sequential logic of mass production, reintegrates production tasks through teamwork, and decentralizes decision-making.

Digital information and communication technologies were not central in the original development of mass production or process enhancement concepts. Mass customization, which was developed in the 1980, is, however, already to a great extent based on new information and communication technologies. It breaks with the linear sequential logic and functional specialization even more than process enhancement and replaces them with an architecture consisting of a product platform and interchangeable modules. Production is carried out through varying processes in a dynamic network of cooperation.

As described by Victor and Boynton (1998), the newest activity concept, co-configuration, is based even more on the utilization of new information and communication technologies. It is characterized by: 1) a customer-intelligent product that can be continuously adapted to changing conditions and customer needs, partly by the producer and partly by the user, 2) a collaborative value-creation system, in which value is not produced in the provider activity nor in the user activity separately, but in the interaction and collaboration between them, 3) continuous customization: the producer does not customize the product or service only once but continuously, and updates it, for instance, through changes in the software. 
The co-configuration concept thus entails continuous, development-oriented dialogue between the producer and the user. Within the producing organization it breaks with the traditional sequential logic of research, product development, production and sales. These phases become rather concurrent aspects in the continuous collaboration between the producer and the user. In business-to-business cooperation, part of the product development is done together with the client in close collaboration in which both parties learn from each other and from the collaboration.

The kind of continuously reconfigured, development-oriented collaboration between specialized organizations described by Victor and Boynton can be seen as an emerging new type of activity concept for the information age. More generally, it seems that in these evolving new concepts, the sequential logic and rigid functional division of labor typical of mass production are being increasingly replaced or complemented with forms of dialogue, the concurrent realization of different aspects of the same activity, and new ways of integrating specialized knowledge and functions in order to master increasingly complex objects.

\section{2.- The development of a new concept for an activity}

According to Victor and Boynton's model, an activity can be developed within the prevailing concept: craft as craft, mass production as mass production etc., or the concept of the activity can be transformed: from craft to mass production, from mass production to process enhancement etc. The latter can be seen as processes of collective expansive learning (Engeström, 1987), in which a new concept is created and implemented to overcome a developmental dead end and an aggravating inner contradiction within the prevailing one. Collective expansive learning processes are typically complex long-term processes in which the actors continuously encounter new contradictions within the activity that they have to overcome expansively. For instance, the evolution of the Toyota production system (and the process enhancement concept) took up to thirty years, according to the account of the process given by head engineer Taiichi Ohno (1978). During these years, several major innovations and innumerable small innovations were made for different aspects of the production activity, such as setups, machine handling, coordination and communication between phases and actors, and internal logistics.

Because of the long time span and complexity of the development of a new concept, maintaining consistency in the process is a special problem. As Vygotsky (1986) notes, a problem or goal does not suffice to start a concept formation process, even though they are necessary prerequisites. Some kind of symbol is also needed to help actors focus their attention and to direct them in the development of the new concept. "The development and use of artificial stimuli play an auxiliary role that permits human beings to master their own behavior, at first by external means and later by more complex inner operations" (Vygotsky, 1978). This idea not only applies to individuals but also to groups and collectives.

When an already known concept is implemented, various representations of the concept can be used as intellectual tools to guide the transformation process. When developing a new concept, consistency cannot be achieved in this way because the content of the new concept is not yet known. A symbol or representation is needed that would paradoxically embody what one does not yet know and what has to (and probably can) be learned or invented (Rheinberger, 1997). One way of doing this is to identify a contradiction within the activity system that must be overcome. In the development of the Toyota production system, for example, that contradiction was first the contradictory demands of the mass-production concept and the small markets in Japan, and later, as Fujimoto (Fujimoto, 1999) has described, the contradictory demands of, on the one hand, good quality, low costs, and punctual delivery, and on the other, worker motivation and well being (in order to diminish employee turnover). 


\section{3.- Inter-organizational collaboration in developing a new concept for an activity}

One way of speeding up the development of new concepts for activities is to extend horizontal collaboration in the development between organizations or units that are carrying out the same kind of activity. Nuovolari and Mayer (Nuovolari, 2001; Mayer, 2003) have described several processes of collective invention in the history of industry - the latest one being the open-source softwaredevelopment process: competent practitioners using the same technical system in different contexts exchange improvements that they have made in the technology. As a result, the technology becomes more robust, and a greater variety of applications are created for different uses. The possibility of collective invention is based on a combination of sameness and variation that makes the exchange possible: the technology is the same, but the users find different problems and possibilities for development in it because they apply it in different contexts and for different purposes.

When the same concept is applied in different local activities, problems related to its use as well as possible solutions are also common. The prevalent activity concepts are in many areas still based on the concepts that evolved during the long post-war period of mass production. The change in the dynamics of industrial development has now brought many of these concepts to a crisis point. Therefore, communality can be found in the historically evolved contradictions in local instances of the same activity. This provides an objective basis for collective invention in the development of a new concept for an activity.

Local activities meet, however, new challenges at different times, the actors involved in them have different hypotheses about the way to overcome the contradictions, and the actors take different paths to overcome the contradictions. Therefore, the communality of the basic contradictions in parallel activity systems is masked by different acute problems and different strategies of development in local activities. The recognition of an essential communality of developmental contradictions behind the acute problems has to be worked out through a special process of analysis and modeling in order to make exchange and collective invention possible in the development of a new concept. The activity-theory based methodology of Developmental Work Research (Engeström, 1987) can be helpful in carrying out such a process.

Combined with a historical and actual empirical analysis of the local activity, Engeström's general model of an activity system (Engeström, 1987) can be used to model the previous concept of the activity and the current internal contradictions within it caused by recent changes in the elements (see Figure 2).

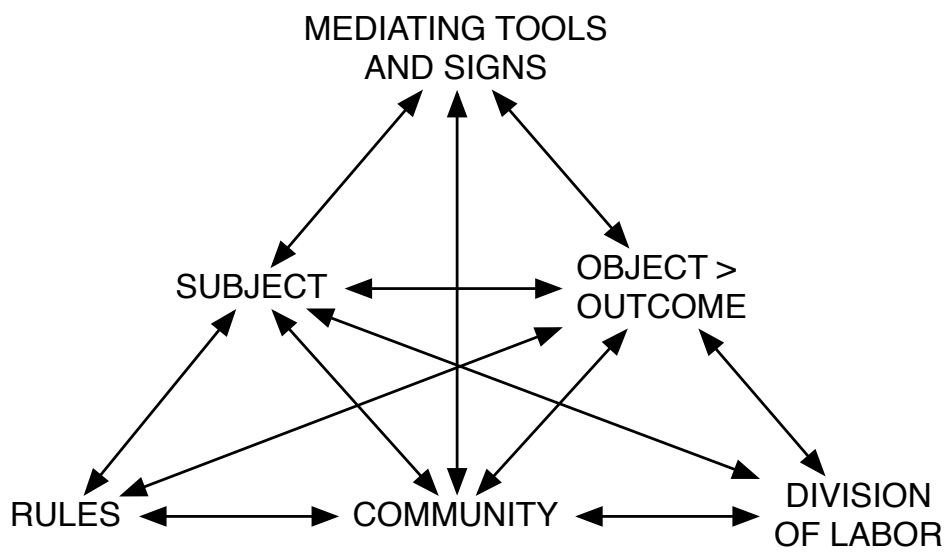

Figure 2. The general model of an activity system

This model depicts an actor in the activity as a member of a community of actors who are working on the same object to produce an outcome. Individual actions and the necessary distribution and exchange of intermediate outputs and resources are mediated through the tools, rules and division of 
labor of the activity system.

The transformation of the concept of a collaborative work activity is a complicated stepwise process of remediation, in which a change in one mediator of the activity creates new inner contradictions within and between elements of the activity system that in turn call for further steps of remediation until the whole activity system has been changed. The process of the expansive transformation of the concept of an activity thus receives its motivating force from the successive emergence and resolution of new types of inner contradictions within the activity system (see Figure 3).

The first phase of the cycle is characterized by a gradual aggravation of the first-order contradiction between use value and exchange value. As further changes in the elements of the activity take place, the in-need state develops into secondary contradictions between elements of the system. These contradictions manifest themselves in individual actors' double-bind situations. The adoption of a new mediator that redefines the object and outcome of the activity starts the process of transforming the activity system. Prompted by collisions between the new and the old elements of the activity, new innovations emerge. In the last phase of the cycle of expansive remediation, new mediators must also be created for the interaction between the central activity and neighboring activities in the network.

Although different local instances of the same activity may share the basic inner contradiction, they can, however, be in a different phase in the process of transforming the activity and creating a new concept for it. Engeström's idealized model of the cycle of expansive transformation of the concept of an activity depicted in Figure 3 (Engeström, 1987) provides a way to model the different phases of transformation of parallel activities and in that way helps the actors see that they are carrying out a similar transformation even though they find themselves in different phases of it.

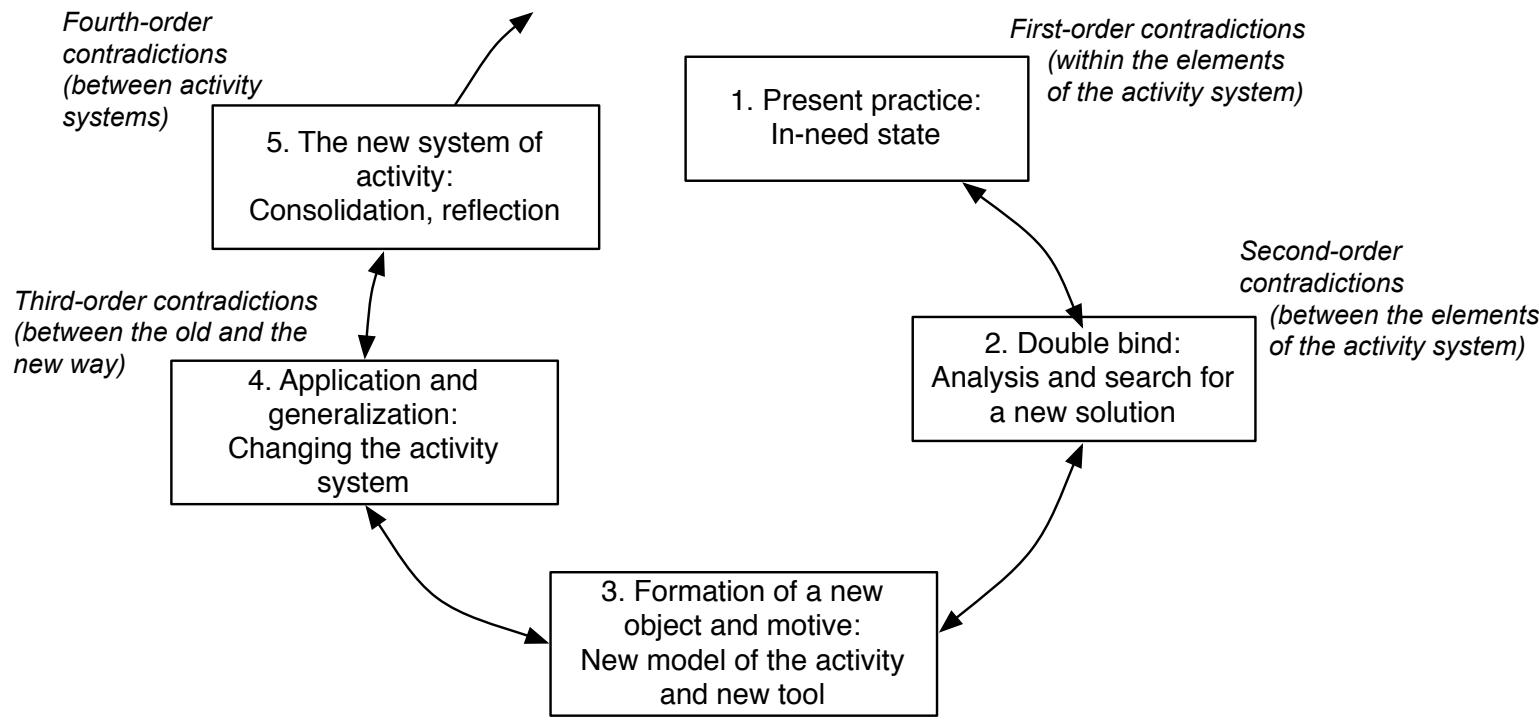

Figure 3. The cycle of expansive transformation of the concept of an activity

In an experimental network between work developers, we are currently testing the hypothesis that collective invention in developing a new concept for a type of activity can be enhanced through helping the actors in local instances of the activity to model the central contradictions of their activity and its current phase in the expansive cycle. Through this type of modeling we expect the actors to identify communalities behind their apparently different problems and thereby find a basis for an exchange of insights and partial innovations in developing the new concept. 


\section{REFERENCING}

Virkkunen, J. (2007). Collaborative development of a new concept for an activity. @etivités, 4 (2), pp. 158164, http://www.activites.org/v4n2/v4n2.pdf

\section{REFERENCES}

Engeström, Y. Learning by expanding: An activity-theoretical approach to developmental research, 1987. Availble at : http://lchc.ucsd.edu/MCA/Paper/Engetrom/expanding /toc.

Freeman, C., \& Louça, F. (2000). As Time Goes By. Oxford: Oxford University Press.

Fujimoto, T. (1999). The evolution of a manufacturing system at Toyota. New York: Oxford University Press.

Mayer, P. M. (2003). Episodes of collective invention. U.S Department of Labor. Bureau of Labor Statistics. Working paper 368, 2003.

Nuovolari, A. (2001). Collective invention during the British industrial revolution. The case of the Cornish pumping engine. Danish Research Unit for Industrial Dynamics. Working Paper 01-05, 2001.

Ohno,T. (1978). The Toyota Production System. Beyond large scale production. Portland Oregon: The Productivity Press.

Rheinberger, H.J. (1997). Toward a history of epistemic things. Synthesizing proteins in the test tube. Stanford California: Stanford University Press.

Victor, B., \& Boynton. A. (1998). Invented Here: Maximizing Your Organization's Internal Growth and Profitability. A Practical Quide to Transforming Work. Boston, Mass.: Harvard Business School Press.

Vygotsky, L. S. (1978). Mind in society. Cambridge, Mass.: Harvard University Press.

Vygotsky, L. S. (1986). Thought and Language. Cambridge Mass.: The MIT Press.

\section{RÉSUMÉ}

Au sein de l'économie de marché, pour toute activité de production, il existe une contradiction intrinsèque entre la valeur d'usage du produit et sa valeur d'échange sur les marchés. Chaque révolution technologique change profondément les conditions d'équilibre de cette contradiction, en permettant la création de nouvelles valeurs d'usage, en offrant des possibilités de réduction des coûts, et en favorisant un élargissement des échanges. Les formes d'activité culturellement disponibles peuvent être considérées comme différents concepts qui correspondent à des équilibres différents de cette contradiction. Actuellement, le concept de production de masse est progressivement remplacé par de nouveaux concepts qui se développent aussi à la faveur de l'exploitation des possibilités fournies par les nouvelles technologies de l'information et de la communication. La création et la mise en œuvre d'un nouveau concept pour une activité est malgré tout un processus complexe, dans lequel beaucoup d'innovations complémentaires doivent être intégrées en un tout fonctionnel. Dans cet article, nous nous proposons de discuter de la possibilité d'appliquer le principe de l'invention collective à la création d'un nouveau concept pour la production.

MoTS CLÉS :

types d'organisation du travail, concept d'activité, système d'activité, invention collective

\section{RESUMEN :}

En toda actividad de producción de la economía de mercado, existe una contradicción intrínseca fundamental entre el valor de uso de un comodity 
producido y su valor de intercambio en el mercado. Cada revolución tecnológica cambia profundamente las condiciones de equilibrio de esta contradicción, permitiendo la creación de nuevos valores de uso, ofreciendo posibilidades de reducción de costos, y favoreciendo la ampliación de los intercambios. Las formas de actividad culturalmente disponibles pueden ser consideradas como diferentes conceptos acerca de cómo se logran equilibrar diferentes exigencias. Actualmente, el concepto de producción en masa está siendo reemplazado por nuevos conceptos que utilizan las posibilidades ofrecidas por las nuevas tecnologías de la información y de la comunicación. La creación e implementación de un nuevo concepto para una actividad es, sin embargo, un proceso complejo en el cual múltiples innovaciones complementarias deben integrarse en un todo funcional. En este artículo, discutiré la posibilidad de aplicar el principio de invención colectiva a la creación de un nuevo concepto operativo/operacional.

Palabras clave:

Tipos de trabajo históricos, el concepto de una actividad, sistema de actividad, invención colectiva 